\title{
Energy balance closure on a winter wheat stand: comparing the eddy covariance technique with the soil water balance method
}

\author{
K. Imukova, J. Ingwersen, M. Hevart, and T. Streck \\ Institute of Soil Science and Land Evaluation, University of Hohenheim, 70593 Stuttgart, Germany \\ Correspondence to: K. Imukova (kristina.imukova@uni-hohenheim.de)
}

Received: 26 March 2015 - Published in Biogeosciences Discuss.: 6 May 2015

Revised: 15 November 2015 - Accepted: 11 December 2015 - Published: 15 January 2016

\begin{abstract}
The energy balance of eddy covariance (EC) flux data is typically not closed. The nature of the gap is usually not known, which hampers using EC data to parameterize and test models. In the present study we crosschecked the evapotranspiration data obtained with the EC method $\left(\mathrm{ET}_{\mathrm{EC}}\right)$ against $\mathrm{ET}$ rates measured with the soil water balance method $\left(\mathrm{ET}_{\mathrm{WB}}\right)$ at winter wheat stands in southwest Germany. During the growing seasons 2012 and 2013, we continuously measured, in a half-hourly resolution, latent heat (LE) and sensible $(H)$ heat fluxes using the EC technique. Measured fluxes were adjusted with either the Bowen-ratio (BR), $H$ or LE post-closure method. $\mathrm{ET}_{\mathrm{WB}}$ was estimated based on rainfall, seepage and soil water storage measurements. The soil water storage term was determined at sixteen locations within the footprint of an EC station, by measuring the soil water content down to a soil depth of $1.5 \mathrm{~m}$. In the second year, the volumetric soil water content was additionally continuously measured in $15 \mathrm{~min}$ resolution in $10 \mathrm{~cm}$ intervals down to $90 \mathrm{~cm}$ depth with sixteen capacitance soil moisture sensors. During the 2012 growing season, the $H$ post-closed LE flux data $\left(\mathrm{ET}_{\mathrm{EC}}=3.4 \pm 0.6 \mathrm{~mm} \mathrm{day}^{-1}\right)$ corresponded closest with the result of the WB method $\left(3.3 \pm 0.3 \mathrm{~mm}^{-1 a y^{-1}}\right)$. $\mathrm{ET}_{\mathrm{EC}}$ adjusted by the BR $\left(4.1 \pm 0.6 \mathrm{mmday}^{-1}\right)$ or LE $\left(4.9 \pm 0.9 \mathrm{~mm} \mathrm{day}^{-1}\right)$ post-closure method were higher than the $\mathrm{ET}_{\mathrm{WB}}$ by 24 and $48 \%$, respectively. In 2013, $\mathrm{ET}_{\mathrm{WB}}$ was in best agreement with $\mathrm{ET}_{\mathrm{EC}}$ adjusted with the $H$ postclosure method during the periods with low amount of rain and seepage. During these periods the BR and LE postclosure methods overestimated ET by about 46 and $70 \%$, respectively. During a period with high and frequent rainfalls, $\mathrm{ET}_{\mathrm{WB}}$ was in-between $\mathrm{ET}_{\mathrm{EC}}$ adjusted by $H$ and $\mathrm{BR}$ post-closure methods. We conclude that, at most observation
\end{abstract}

periods on our site, LE is not a major component of the energy balance gap. Our results indicate that the energy balance gap is made up by other energy fluxes and unconsidered or biased energy storage terms.

\section{Introduction}

The eddy covariance (EC) method is a widely used, longstanding method to directly measure turbulent energy and matter fluxes near the land surface. As a quality check, the energy balance closure (EBC) of eddy covariance flux measurements may be computed. According to the first law of thermodynamics, energy must be conserved. At the land surface, the surface energy budget equation, written here for its major components, must be fulfilled:

$R_{\mathrm{n}}=\mathrm{LE}+H+G$.

Here, $R_{\mathrm{n}}\left(\mathrm{W} \mathrm{m}^{-2}\right)$ is net radiation, and LE $\left(\mathrm{W} \mathrm{m}^{-2}\right)$ and $H$ $\left(\mathrm{W} \mathrm{m}^{-2}\right)$ denote the latent heat and sensible heat flux, respectively. The symbol $G\left(\mathrm{~W} \mathrm{~m}^{-2}\right)$ stands for the ground heat flux. Minor flux terms such as energy storage in the canopy or energy conversion by photosynthesis are generally neglected (see e.g., Leuning et al., 2012). However, several studies, where minor energy fluxes were carefully investigated as potential sources for the imbalance, show that considering these minor terms is relevant (Lamaud et al., 2001; Meyers and Hollinger, 2004; Oncley et al., 2007) and could even in some cases help to achieve a nearly perfect EBC (Jacobs et al., 2008).

Usually the sum of the two turbulent fluxes measured with the EC method is systematically lower than the so-called available energy: the difference between net radiation $\left(R_{\mathrm{n}}\right)$ 
and ground heat flux $(G)$. As a consequence, the energy balance at the Earth's surface usually cannot be closed with the $\mathrm{EC}$ technique. The quotient of turbulent fluxes and available energy expresses the energy balance closure:

$\mathrm{EBC}=\frac{(H+\mathrm{LE})}{\left(R_{\mathrm{n}}-G\right)}$.

In general, EBC ranges between 70 and $90 \%$ as observed over different types of surface ranging from bare soil to a forest (Oncley et al., 2007; Wilson et al., 2002; Twine et al., 2000). Low EBCs (60-80\%) were mainly observed at various agricultural sites and bare soil, whereas over forest they were typically higher (80-90\%) (Charuchittipan et al., 2014; Wilson et al., 2002; Foken, 2008a; Panin and Bernhofer, 2008; Stoy et al., 2013). The imbalance usually occurs during day time, particularly around noon, whereas during the night when fluxes are low EBC is often close to unity (Oncley et al., 2007).

It was long thought that the energy balance gap originates from the instrumental errors of the EC-measurements. However, the accuracy of the energy flux measurements and data quality has significantly increased during the last years. According to Foken (2008a), measuring errors cannot explain the problem of the imbalance provided that measurements and data processing were performed carefully. In a more recent paper, Foken et al. (2010) investigated the EBC of the LITFASS-2003 experimental data. He concluded that the observed lack of EBC on the local scale in heterogeneous landscape can be explained only by deficits in measurement concepts and methodologies. This conclusion is supported by Heusinkveld et al. (2004); they found a perfect EBC over a homogeneous surface: a desert in Israel. Tsvang et al. (1991) and Stoy et al. (2013) also concluded that the heterogeneities of the surrounding area are an important factor contributing to the lack of EBC. Several authors (Klaassen and Sogachev, 2006; Friedrich et al., 2000) reported an increase of the turbulent fluxes at forest edges. Kanda et al. (2004) and Inagaki et al. (2006) used large eddy simulations (LES) to study the contribution of large eddies to energy exchange. They found out that the energy balance can be significantly improved by considering contributions from secondary circulations or turbulent organized structures. The secondary circulations are large-scale eddies, they are relatively stationary and are induced, for example, by surface heterogeneities (Foken, 2008a). Due to their large size and slow motion, their transport of heat, water or gas is not detectable by a single EC station. Energy transfer by such large eddies has to be modeled or measured with an area-averaging method (Foken, 2008a; Stoy et al., 2013). Mauder et al. (2007) analyzed airborne flux measurements over a boreal ecosystem in Canada in order to quantify secondary circulation fluxes. They found that these fluxes were in the same order of magnitude as energy balance residuals observed at EC stations close to the flight track. However, this large eddy theory has not been fully embraced by the scientific community. Leun- ing et al. (2012), for instance, evaluated EBC of the La Thuile data set. He concluded that unrealistically large and positive horizontal gradients in temperature and humidity would be needed for advective flux divergences in order to explain the EBC problem at half-hourly timescale. Other potential reasons for the imbalance discussed in the literature relate to the possible loss of low- and/or high-frequency components (Wolf et al., 2007; Sakai et al., 2001; Barr et al., 1994). A small fraction of the energy balance gap may also be explained by energy storage in the canopy and photosynthetic energy flux. Both components are normally neglected due to their alleged small contribution (Foken, 2008a; Guo et al., 2009; Jacobs et al., 2008).

The uncertainty arising from the energy balance gap hampers the use of EC data for model parameterization and testing (Ingwersen et al., 2011; El Maayar et al., 2008; Falge et al., 2005). In these types of studies, in order to achieve an energy balance closure, the measured turbulent fluxes are usually adjusted with either $H$ flux, LE flux or the Bowen ratio (BR) post-closure method. These methods fully add the residual to the measured turbulent fluxes, assuming that the available energy is measured correctly. The $H$ post-closure method, letting the latent heat flux unaltered, adds the gap fully to the measured $H$ flux (Ingwersen et al., 2011; Gayler et al., 2013). Oppositely, the LE flux post-closure method assigns the lacking energy fully to LE (Falge et al., 2005). The BR post-closure method assumes that the energy residual has the same Bowen ratio $(\mathrm{Bo}=H / \mathrm{LE})$ as the measured turbulent fluxes (Twine et al., 2000; Barr et al., 1994). In this case, the adjusted LE flux $\left(\mathrm{LE}^{*}, \mathrm{Wm}^{-2}\right)$ is computed as follows:

$\mathrm{LE}^{*}=\frac{R_{\mathrm{n}}-G}{\mathrm{Bo}+1}$.

The present study elucidates the nature of the energy balance gap over winter wheat in southwest Germany. For this purpose we (a) evaluated the energy balance of EC flux measurements over two vegetation seasons, additionally measuring evapotranspiration with the soil water balance method $\left(\mathrm{ET}_{\mathrm{WB}}\right)$, which does not depend on an a priori assumption on the composition of the energy residual, and (b) tested $\mathrm{ET}_{\mathrm{EC}}$ adjusted by the BR, $H$ or LE post-closure method against the $\mathrm{ET}_{\mathrm{WB}}$.

\section{Materials and methods}

\subsection{Study site}

The present study was performed in the region Kraichgau (Fig. 1), one of the warmest regions in Germany. Mean annual temperature ranges between $9-10^{\circ} \mathrm{C}$, and precipitation between 730 and $830 \mathrm{~mm}$ per year. The rivers Neckar and Enz form the borders in the east. In the north and in the south, Kraichgau is bounded by the low mountain ranges of Odenwald and the Black Forest. In the west, Kraichgau borders on the Upper Rhine plain. The Kraichgau area is about 

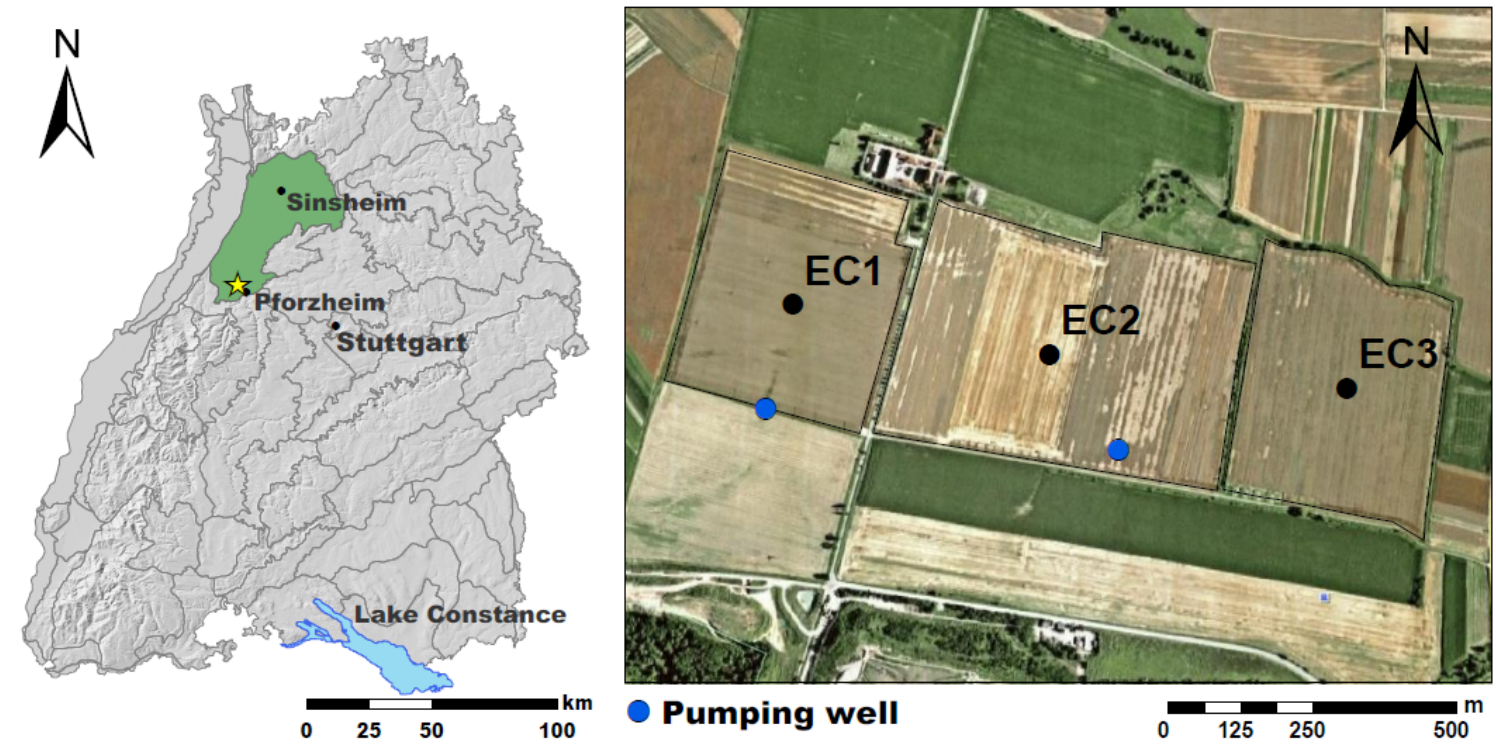

Figure 1. The study region "Kraichgau" (green) on the map of the federal state Baden-Württemberg. Location of the central study site is indicated by a yellow star. The right panel shows a close-up of the central study site. That site consists of three fields (EC1-3). An eddy covariance station (black full point) is installed in the center of each field.

$1600 \mathrm{~km}^{2}$ and has a gently sloping landscape. Elevations vary between 200 and $320 \mathrm{~m}$ above sea level (a.s.l.). Soils, predominantly classified as Luvisols (IUSS Working Group WRB, 2007), were mostly formed here from periglacial loess, which accumulated during the last ice age. Today, the region is intensively used for agriculture. Around $53 \%$ of the total area is used for crop production. Winter wheat, winter rape, summer barley, maize and sugar beet are the predominant crops.

The measurements were performed at the agricultural fields EC1 and EC3 belonging to the farm "Katharinentalerhof" (Fig. 1). The fields are located north of the city of Pforzheim $\left(48.92^{\circ} \mathrm{N}, 8.70^{\circ} \mathrm{E}\right)$. The fields EC1 and EC3 are 14 and 15 ha in size, respectively. The terrain is flat (elevation a.s.1.: $319 \mathrm{~m}$ ). The predominant wind direction is south-west. Both fields are surrounded by other agricultural fields, which are separated partly by tree-hedges. Two permanent pumping wells (installation depth $3 \mathrm{~m}$ ) were used to monitor the groundwater table (see Fig. 1). The soil type at both fields is Stagnic Luvisol (IUSS Working Group WRB, 2007). Basic soil properties are given in Table 1. In both 2012 and 2013, fields were cropped with winter wheat (Triticum aestivum L. $\mathrm{cv}$. Akteur). In both years, winter wheat was drilled on 17 October.

\subsection{Measurement of evapotranspiration}

\subsubsection{Eddy covariance technique}

Using the EC technique, we measured the land surface exchange fluxes in a 30 min resolution at two study fields (EC1 and EC3). Both sites were cropped with winter wheat. The
EC method enables measuring the heat, energy and momentum exchange between land surface and atmosphere without disturbing the crop environment. Provided that the land surface is sufficiently flat and homogeneous, the exchange fluxes are one-dimensional and can be calculated from the covariance between vertical wind speed and the scalar of interest. In the case of the LE flux ( $\mathrm{W} \mathrm{m}^{-2}$ ) this leads to

$\mathrm{LE}=\lambda \rho \overline{q^{\prime} w^{\prime}}$,

where $\lambda\left(\mathrm{J} \mathrm{kg}^{-1}\right)$ and $\rho\left(\mathrm{kg} \mathrm{m}^{-3}\right)$ are the heat of vaporization and the density of air, respectively. The symbol $q\left(\mathrm{~kg} \mathrm{~kg}^{-1}\right)$ stands for the specific humidity of the air, and $w\left(\mathrm{~m} \mathrm{~s}^{-1}\right)$ denotes the vertical wind speed. The term $\overline{q^{\prime} w^{\prime}}$ is the covariance between the fluctuations of the two quantities.

The EC stations were installed in the center of each study field in April 2009. The stations were equipped with an open path infrared $\mathrm{CO}_{2} / \mathrm{H}_{2} \mathrm{O}$ gas analyzer (Licor 7500, LI-COR Biosciences, USA) and a 3-D sonic anemometer (CSAT3, Campbell Scientific, UK). At EC3 (2012) the turbulent complex was installed at a height of $2.63 \mathrm{~m}$. The Licor-CSAT3 separation distance was $0.22 \mathrm{~m}$. The direction of Licor 7500 was $25^{\circ}$ against north, CSAT3 orientation was $170^{\circ}$. At EC1 (2013), the turbulent complex was installed at a height of $3.10 \mathrm{~m}$ with a sensor separation of $0.12 \mathrm{~m}$. Orientations of Licor 7500 and CSAT3 were 0 and $170^{\circ}$, respectively. Vertical wind speed and specific humidity were measured with $10 \mathrm{~Hz}$ frequency. All other sensors recorded data in 30 min intervals. Net radiation was measured with a NR01 4component sensor (NR01, Hukseflux Thermal Sensors, The Netherlands). Air temperature and humidity were measured in $2 \mathrm{~m}$ height (HMP45C, Vaisala Inc., USA). Rainfall was 
Table 1. Basic soil properties of the fields EC1 and EC3. At both sites the soil type is Stagnic Luvisol (IUSS Working Group WRB, 2007).

\begin{tabular}{lccccc}
\hline $\begin{array}{l}\text { Depth } \\
(\mathrm{cm})\end{array}$ & $\begin{array}{c}\text { Bulk density } \\
\left(\mathrm{g} \mathrm{cm}^{-3}\right)\end{array}$ & $\begin{array}{c}\text { Texture } S / U / C^{*} \\
(\% \text { by weight })\end{array}$ & $\begin{array}{c}\text { Organic matter content } \\
(\% \text { by weight })\end{array}$ & $\begin{array}{c}\text { Carbonate content } \\
(\% \text { by weight })\end{array}$ & $\begin{array}{c}\mathrm{pH} \\
\left(0.01 \mathrm{M} \mathrm{CaCl}_{2}\right)\end{array}$ \\
\hline EC1 & & & & & 6.9 \\
$0-30$ & 1.49 & $3.4 / 81.2 / 15.4$ & 1.54 & 0.29 & 6.7 \\
$30-60$ & 1.50 & $3.4 / 81.6 / 15.0$ & 0.31 & 0.31 & 6.6 \\
$60-90$ & 1.47 & $2.8 / 81.6 / 15.6$ & 0.27 & 0.27 & 6.6 \\
$90-120$ & 1.47 & $2.8 / 81.1 / 16.1$ & 0.53 & 0.37 & 6.6 \\
$120-150$ & 1.48 & $2.4 / 80.0 / 17.6$ & 0.33 & & 6.13 \\
EC3 & & & & 0.10 & 6.5 \\
$0-30$ & 1.43 & $3.4 / 81.2 / 15.4$ & 1.60 & 0.12 & 6.6 \\
$30-60$ & 1.49 & $3.7 / 80.6 / 15.7$ & 0.31 & 0.13 & 6.6 \\
$60-90$ & 1.47 & $2.3 / 80.9 / 16.7$ & 0.62 & 0.05 & 6.6 \\
$90-120$ & 1.51 & $1.8 / 80.5 / 17.7$ & 0.40 & & \\
$120-150$ & 1.55 & $1.5 / 80.3 / 18.2$ & 0.34 & & \\
\hline
\end{tabular}

* Fraction of sand $(S)$, silt $(U)$, clay $(C)$.

measured using a tipping bucket (resolution: $0.2 \mathrm{~mm}$ per tip). The rain gauge (ARG100, Campbell Scientific Ltd., UK) was located close to the EC station. The rain gauge readings $(R$, in $\mathrm{mm} \mathrm{h}^{-1}$ ) were corrected for catching, wetting and evaporation losses according to $\mathrm{WMO}(2009$, p. 57):

$R_{\text {cor }}=1.21 R^{0.92}$.

Soil sensors were also installed close to the EC station. Temperature probes (107 Thermistor probe, Campbell Scientific Inc., UK) were installed in 2, 6, 15, 30 and $45 \mathrm{~cm}$ depth. The volumetric water content was measured with TDR probes (CS616, Campbell Scientific Inc., UK) at 5, 15, 30, 45 and $75 \mathrm{~cm}$ depth. Three soil heat flux plates (HFP01, Huskeflux Thermal Sensors, the Netherlands) were installed in $8 \mathrm{~cm}$ depth. For measuring the hydraulic gradient at the lower boundary of the water balance domain, two matric potential sensors (257-L, Campbell Scientific Ink., UK) were installed in $130 \mathrm{~cm}$ and three sensors in $150 \mathrm{~cm}$ depth. The horizontal distance between sensors was about $50 \mathrm{~cm}$.

The EC flux data were processed with the TK3.1 software (Mauder and Foken, 2011). Surface energy fluxes were computed from 30 min covariances. Data points exceeding 4.5 standard deviations in a window of 15 values were labeled as spikes and were excluded from the time series. The planar fit coordinate rotation was applied to time periods of 10-14 days. Spectral losses were corrected according to Moore (1986). The fluctuation of sonic temperature was converted into actual temperature according to Schotanus et al. (1983). Density fluctuations were corrected by WPL (Webb et al., 1980). For data quality analysis we used the flag system after Foken (Mauder and Foken, 2011). Half-hourly values with flags from 1 to 6 (high and moderate quality data) were used to calculate the energy balance closure and evapotranspiration. Gap filling of EC flux data was performed with the mean diurnal variation method using an averaging window of 14 days (Falge et al., 2001). Additionally we com- puted the random error of the fluxes, which consist of the instrumental noise error of the EC station and the stochastic (sampling) error (Mauder et al., 2013).

The EC ET $\left(\mathrm{L} \mathrm{m}^{-2}\right.$ or $\left.\mathrm{mm}\right)$ per half hour was estimated with the following equation:

$\mathrm{ET}_{\mathrm{EC}}=\frac{\mathrm{LE}}{\lambda} \times 1800 \mathrm{~s}$,

where the heat of vaporization $\lambda\left(\mathrm{J} \mathrm{L}^{-1}\right)$ as a function of temperature $T\left({ }^{\circ} \mathrm{C}\right)$ (Foken, 2008b) was taken as

$\lambda=2501000-2370 \times T$.

Subsequently, $\mathrm{ET}_{\mathrm{EC}}$ values were adjusted by the $H$, LE or Bowen ratio post-closure method.

Ground heat flux was calculated as the sum of measured soil heat flux using the mean of the three heat flux plates and the heat storage change $\left(\Delta S_{G}\right)$ (Eq. 8) between the surface and the plates (Foken, 2008b)

$\Delta S_{G}=\frac{C_{\mathrm{v}} \times \Delta T \times L}{\Delta t}$,

where $C_{\mathrm{v}}\left(\mathrm{J} \mathrm{m}^{-3}{ }^{\circ} \mathrm{C}^{-1}\right)$ is the volumetric heat capacity of the soil, $\Delta T\left({ }^{\circ} \mathrm{C}\right)$ denotes the soil temperature change during the period of time, $\Delta t$, considered, and $L(\mathrm{~m})$ is the thickness of the soil layer above the soil heat flux plates. The heat capacity of the soil was computed according to de Vries (1963) using the volumetric water content measured in $5 \mathrm{~cm}$ depth.

\subsubsection{Soil water balance method}

The water balance equation of a soil volume of a unit area and given depth reads as follows:

$\mathrm{ET}_{\mathrm{WB}}=R-\mathrm{SP}-\mathrm{SR}-\Delta S$. 

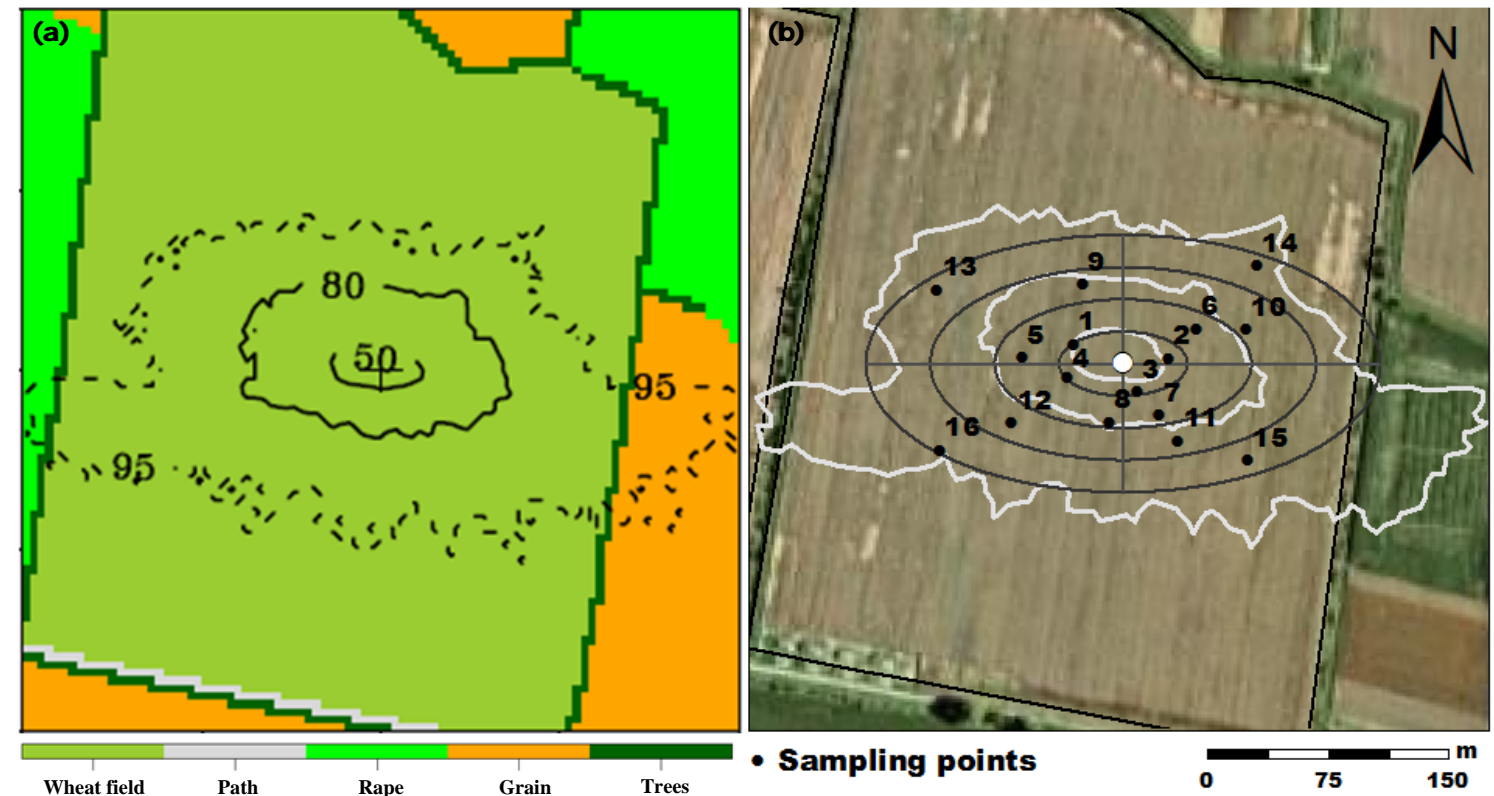

Figure 2. (a) Footprint of the eddy covariance station EC 3 in 2012. Black isolines indicate the fraction of the source area of 50,80 and $95 \%$ of measured EC fluxes. (b) Positions of sampling points within the footprint of EC3 used to measure soil water storage.

Here, $R$ stands for rainfall, and $\mathrm{SP}$ is seepage (negative: capillary rise, positive: vertical drainage). The symbol SR denotes surface runoff and $\Delta S$ stands for the change in soil water storage over the balancing period. Based on our field observations, SR was negligible at the study sites during the periods considered.

$\Delta S$ was measured at sixteen positions. Sampling positions were distributed across the footprint of the EC station using a stratified random sampling design (Figs. $2 \mathrm{~b}$ and $3 \mathrm{~b}$ ). To check whether the measured $\Delta S$ values are uncorrelated (independent) we computed semi-variograms and spatially interpolated $\Delta S$ over the footprint. The geostatistical analysis was performed with ArcGIS (Version 10.3, ESRI Inc.). The point data were interpolated with the Ordinary Kriging method. No trend removal was applied and isotropy was assumed.

The footprint area of the EC station was determined with the forward Lagrangian stochastic footprint model described by Göckede et al. (2006) based on EC flux data in 2010 (EC3) and 2011 (EC1). In these years, the fields were also cropped with winter wheat (Triticum aestivum cv. Cubus (EC3) and $\mathrm{cv}$. Akteur (EC1)). The model estimates the footprint for different atmospheric stratifications (stable, neutral and unstable). In the present study, we used the weighted average footprint of these atmospheric stratifications. Footprint analyses were processed for periods from mid-May to late July, when the average plant height was about constant, on average 0.77 and $0.83 \mathrm{~m}$ at EC3 and $\mathrm{EC} 1$, respectively. The installation height of CSAT was $2.5 \mathrm{~m}$ at EC3 and $3.10 \mathrm{~m}$ at EC1 over the entire periods. The footprint model requires a land use and a roughness matrix as input files. Based on the satellite remote- sensing data, we produced land use matrices of the surroundings of the EC stations. The special spatial resolution of matrices was $5 \mathrm{~m}$ and their areal coverage $500 \times 500 \mathrm{~m}^{2}$. The subsequent land use types were counted: winter wheat, path, rape, grain, trees and suburban. Roughness values of the land use classes were taken from Foken (2008b) (Figs. 2a and 3a).

In 2012, we performed three soil sampling campaigns over the growing season: late April (25-27), mid-June (1415) and late July (24-27). In 2013, four sampling campaigns were performed: mid-April (15-16), early June (3-4), mid-June (18-19) and late July (30-31). Soil samples were taken in $10 \mathrm{~cm}$ intervals down to $150 \mathrm{~cm}$. For this purpose, three augers with a length of $60 \mathrm{~cm}(\varnothing=2.885 \mathrm{~cm}), 100 \mathrm{~cm}$ $(\varnothing=2.386 \mathrm{~cm})$ and $150 \mathrm{~cm}(\varnothing=1.763 \mathrm{~cm})$ were used. The $60 \mathrm{~cm}$ auger was used for taking soil samples down to $60 \mathrm{~cm}$. The $100 \mathrm{~cm}$ auger was used for sampling the $60-100 \mathrm{~cm}$ depth, and the $150 \mathrm{~cm}$ auger was taken for sampling between 100 to $150 \mathrm{~cm}$. Soil samples were filled in plastic bags and transported to the lab within less than $10 \mathrm{~h}$. Field wet soil samples were weighed, put into a ventilated oven and dried at $105^{\circ} \mathrm{C}$. Final weights were usually reached within $12 \mathrm{~h}$. Based on mass balance, the gravimetric water content was calculated. It was converted to volumetric water content by multiplication with the bulk density. Bulk density of the topsoil layers $(0-30 \mathrm{~cm})$ was determined at each sampling position using a cylindrical steel core cutter (diameter: $7.92 \mathrm{~cm}$, volume for a $10 \mathrm{~cm}$ sampling depth: $492.7 \mathrm{~cm}^{3}$ ) on 4 May in 2012 and on 30 April in 2013. In three $10 \mathrm{~cm}$ intervals the core cutter was inserted into the soil by careful turning. The soil sample was stored in a plastic bag and in the lab the soil dry weight was determined by drying the sample at $105^{\circ} \mathrm{C}$. 

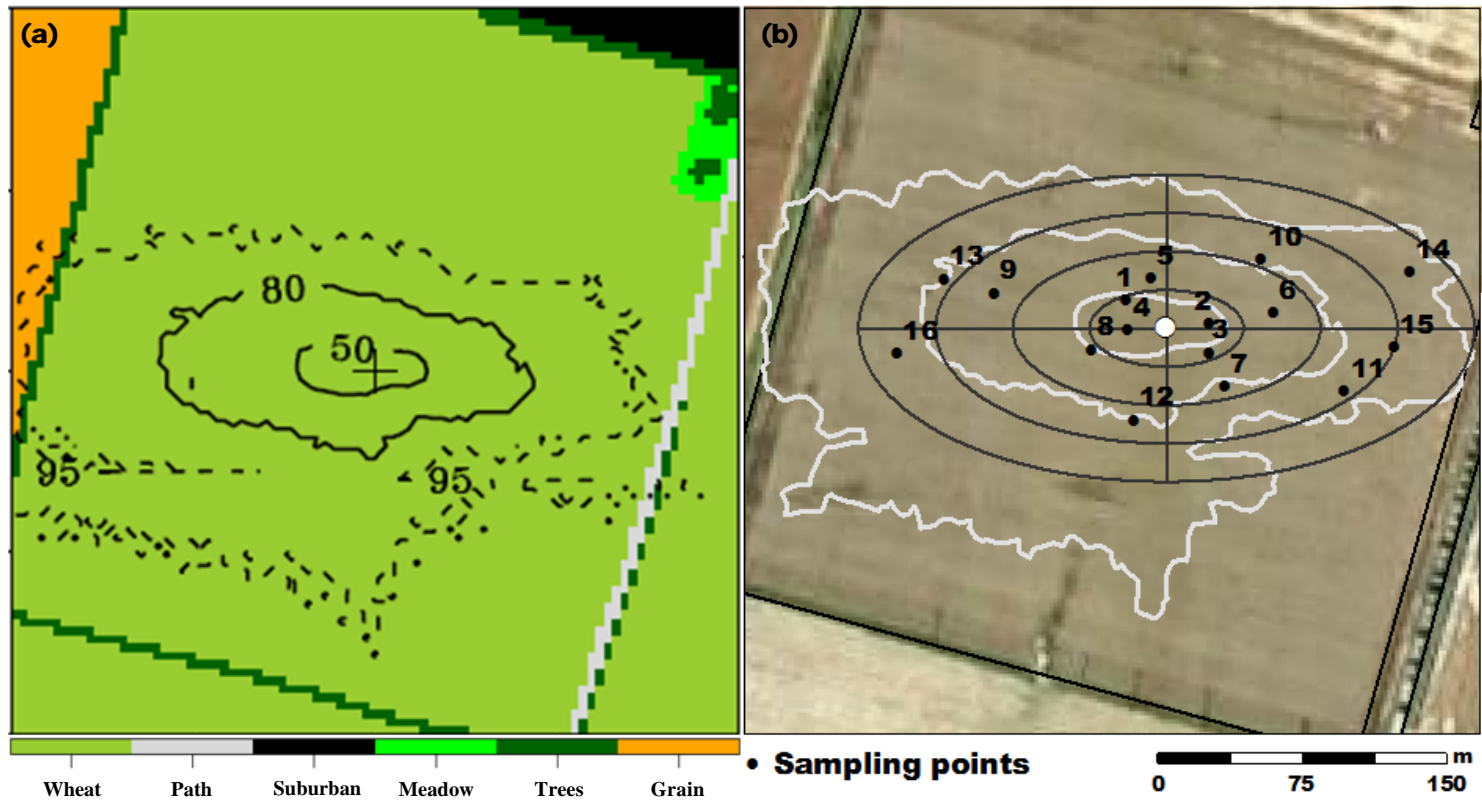

Figure 3. (a) Footprint of the eddy covariance station EC 1 in 2013. Black isolines indicate the fraction of the source area of 50,80 and $95 \%$ of measured EC fluxes. (b) Positions of sampling points within the footprint of EC3 used to measure soil water storage.

Close to the EC station a pit was dug down to $150 \mathrm{~cm}$. In the center of every $10 \mathrm{~cm}$ layer, $100 \mathrm{~cm}^{3}$ of soil was sampled in triplicates using cylindrical cores $(\varnothing=5.50 \mathrm{~cm}$, height $4.21 \mathrm{~cm}$ ). Bulk density was determined by drying the soil at $105^{\circ} \mathrm{C}$ and determining its mass by weighing.

At the $140 \mathrm{~cm}$ depth we took soil samples to measure the water retention curve and the hydraulic conductivity function. Samples $\left(V=250 \mathrm{~cm}^{3}, \varnothing=8 \mathrm{~cm}, 5 \mathrm{~cm}\right.$ height) were taken in triplicates using sampling rings (UMS GmbH, Germany).

Additionally, soil texture was determined at each sampling position. Three layers $(0-30,30-60,60-90,90-120$, and $120-150 \mathrm{~cm}$ ) were pooled to one composite sample and soil texture was determined with the standard pipette method (Dane and Topp, 2002).

The seepage flux was computed from the DarcyBuckingham law:

$q_{\mathrm{w}}=-K(h) \frac{\Delta H}{\Delta z}$.

Here, $q_{\mathrm{w}}\left(\mathrm{cm} \mathrm{d}^{-1}\right)$ is the water flux density, $K(h)\left(\mathrm{cm} \mathrm{d}^{-1}\right)$ denotes the hydraulic conductivity as a function of the matric potential $h(\mathrm{~cm})$, and $H(\mathrm{~cm})$ is the hydraulic potential, the sum of matric and gravitational potentials. The hydraulic gradient $\Delta H / \Delta z$ was computed from the matric potential measurements performed at 130 and $150 \mathrm{~cm}$ depth and the vertical separation distance $\Delta z(\mathrm{~cm})$ of the matric potential sensors.

The hydraulic conductivity function $K(h)$ was determined with the evaporation method according to Wind/Schindler using the HYPROP lab system (UMS GmbH, Germany).
First, soil samples taken from the $140 \mathrm{~cm}$ depth were slowly saturated for 5-6 days. Afterwards soil samples were placed on a balance and exposed to evaporation. The matric potential was measured with micro-tensiometers in 1.25 and $3.75 \mathrm{~cm}$ depth. The soil sample weight and the matric potential were recorded automatically every minute at the first hour and every $10 \mathrm{~min}$ in the next hours. After 4 to 5 days, the tensiometers fell dry and the measurement was stopped. The initial water content of soil samples was computed from their dry weight. Based on the acquired data, a water retention curve and hydraulic conductivity function were fitted to the data. Parameters of the functions were fitted with the robust, non-linear optimizing procedure developed by Durner and Peters (2006) (User Manual HYPROP, 2012). Among the available hydraulic models, the bimodal van Genuchten parameterization (Durner, 1994) yielded the lowest Akaike information criterion and was used in the following to model $K(h)$ :

$$
\begin{aligned}
& K(h)=K_{\mathrm{S}} \cdot\left[\sum_{j=1}^{2} w_{j}\left[1+\left(a_{j}|h|\right)^{n_{j}}\right]^{1 / n_{j}-1}\right]^{\tau} \\
& {\left[\frac{\sum_{j=1}^{2} w_{j} a_{j}\left\{1-\left(a_{j}|h|\right)^{n_{j}-1}\left[1+\left(a_{j}|h|\right)^{n_{j}}\right]^{1 / n_{j}-1}\right\}}{\sum_{j=1}^{2} w_{j} a_{j}}\right]^{2}} \\
& j=(1,2)
\end{aligned}
$$

In Eq. (10), $K_{\mathrm{s}}\left(\mathrm{cm} \mathrm{d}^{-1}\right)$ is saturated hydraulic conductivity, $w_{j}$ is the weighting factors of the two van Genuchten func- 
tions and $a_{j}, n_{j}$ are the shape parameters of the two retention curves. The tortuosity factor $\tau$ was set to 0.5 . $K_{\mathrm{S}}$ was measured on soil samples taken at EC1 from $140 \mathrm{~cm}$ depth by the falling head technique using a KSAT system (UMS GmbH, Germany). The methodology of the device follows the German standard DIN 18130-1 and is based on the inversion of the Darcy law (Operation Manual KSAT, 2013). Measurement of $K_{\mathrm{S}}$ was repeated five times with each of three samples. The average value of $K_{\mathrm{S}}$ was $39.3 \mathrm{~cm} \mathrm{day}^{-1}$.

In 2013, we additionally measured the volumetric soil water content with capacitance soil moisture probes (SM1, Adcon Telemetry, Austria). The probes were installed on 17 and 18 December 2012. The soil moisture network consisted of sixteen stations located at the same positions where soil samples were taken (Fig. 3b). Every station was situated in the middle between two machine tracks, so the farmer could easily pass the station during fertilization and pesticide application. Each station consisted of a nine-level SM1 capacitance probe, remote transfer unit (RTU) (addIT A723 Series 4, Adcon Telemetry, Austria) and a solar panel for power supply.

Adcon SM1 sensors measure the capacitance and are characterized by low power consumption. Their radius of influence is about $10 \mathrm{~cm}$. In order to install the SM1 probes, we removed the soil with a screw auger and then carefully installed the moisture sensors. To avoid air voids between sensor and soil, the bore hole was carefully filled up with soil slurry. The RTU and solar panel were mounted to an aluminum mast and installed about $2 \mathrm{~m}$ away from the SM1 sensor.

The volumetric water content was measured for $15 \mathrm{~min}$ intervals at $10 \mathrm{~cm}$ resolution down to $90 \mathrm{~cm}$ depth. Soil moisture content was measured from 1 April to 4 August 2013. Each RTU stored and transmitted the data to the so-called master station (RA440, Adcon Telemetry, Austria) mounted on the EC mast. The master station transferred the data via GSM modem to the central data server (A850 Telemetry Gateway, Adcon Telemetry GmbH, Austria) located at the University of Hohenheim.

The SM1 sensors were calibrated separately using the data of the four sampling campaigns in 2013 described above. Soil samples were taken about $30-50 \mathrm{~cm}$ away from the sensor. The calibration line was derived by regressing volumetric water content measured by the sensor to that of measured in the lab.

Mean diurnal $\mathrm{ET}_{\mathrm{WB}}$ and $\mathrm{ET}_{\mathrm{EC}}$, adjusted by the $\mathrm{BR}, H$ or LE post-closure methods, were estimated and compared in 6 OPs (OP) (Tables 2 and 3). In OP-1, OP-2, OP-3 and OP-6, ET $\mathrm{WB}_{\mathrm{B}}$ was estimated based on data obtained during the soil sample campaigns, whereas in OP-4 and OP-5 it was estimated based on the data of SM1 sensors. The latter two periods are characterized by low precipitation and seepage, which helps minimize uncertainties in drainage calculations (Fig. 4).

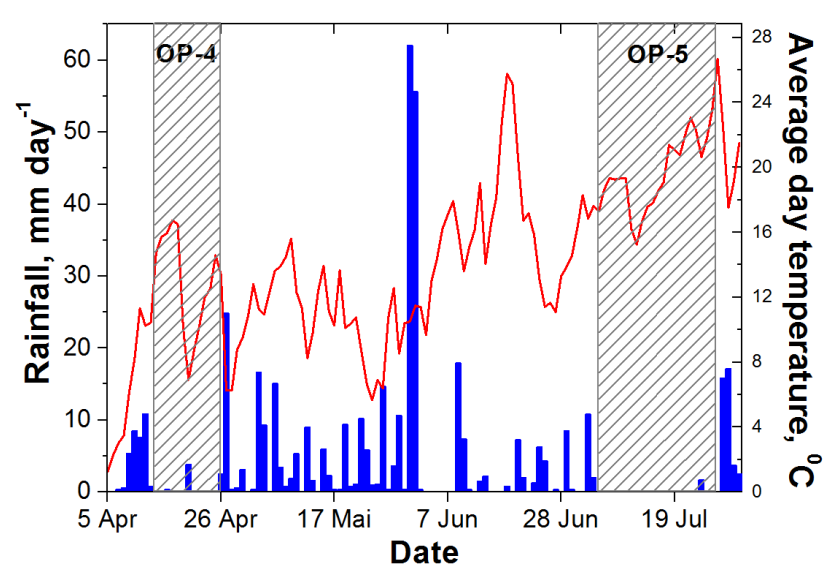

Figure 4. Diurnal rainfall and mean temperature during the 2013 growing season. Hatched zones (OP-4, OP-5) indicate periods with low amount of rain and seepage.

\subsection{Error estimation}

The error of measured ET $\mathrm{WB}_{\mathrm{WB}}$ was estimated based on the Gaussian error propagation law (Currell and Dowman, 2009):

$s_{\mathrm{ET}}=\sqrt{s_{R}^{2}+s_{\mathrm{SP}}^{2}+s_{\Delta S}^{2}}$.

Here, $s$ is the standard error of the corresponding variables $R, \mathrm{SP}$ or $\Delta S$. The standard error of rainfall was calculated based on the observations of the three rain gauges (EC1-3) $(n=3)$. The standard error of $\Delta S$ was computed from the soil water content measurements that were performed every campaign at 16 positions $(n=16)$. In order to evaluate an error of SP estimates, we used the three sets of the bimodal van Genuchten parameterization, which were determined in the lab (see chapter 2.2.2). For each parameterization the drainage and capillary rise were estimated $(n=3)$.

\section{Results}

\subsection{Energy balance closure of eddy covariance data}

The EBC of high-quality data (1-3 flags after Foken) and excluding low LE fluxes $\left(-25 \mathrm{~W} \mathrm{~m}^{-2}<\mathrm{LE}<25 \mathrm{~W} \mathrm{~m}^{-2}\right)$ was $73 \%$ during the growing season 2012 and $67 \%$ from midJune to late July in 2013. The average random error was $16 \%$ for both LE and $H$ in 2012. In 2013, the random error of LE was $12 \%$ and that of $H$ was $14 \%$. In total, $43 \%$ of the data fulfilled the above quality criteria. Allowing in addition for moderate quality data (4-6 flags after Foken), EBC decreased on average by about 2 and $4 \%$ in 2012 and 2013, respectively. Table 3 summarizes the EBC in different OPs estimated based on high and moderate quality data. In 2012, from late April to late July the average EBC was about 


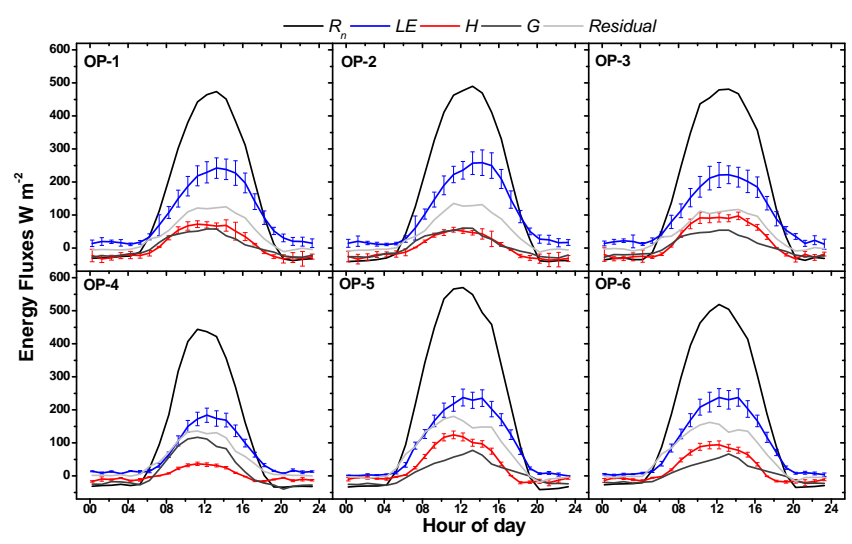

Figure 5. Averaged diurnal cycles of net radiation $R_{\mathrm{n}}$, latent LE, sensible $H$ and ground heat fluxes $G$ in the observation periods (OPs) of 2012 (OP 1-3) and 2013 (OP 4-6).

$71 \%$. This EBC was uniform during different OPs. The average residual was $68.5 \mathrm{~W} \mathrm{~m}^{-2}$. The random error of LE was $18 \%$, that of $H 19 \%$. In 2013, we observed a lower EBC of about $60 \%$. The average residual was $86.1 \mathrm{Wm}^{-2}$. The average random error of flux measurements was $16.5 \%$ for LE and $18 \%$ for $H$. The lowest EBC of about $57 \%$ was measured from mid-April to early June. During this period, $55 \%$ of days were rainy days (Fig. 4) resulting in a large amount of rainfall $(250 \mathrm{~mm}$ ) - about $50 \%$ higher than in 2012 (Table 2). In this period we also measured the lowest net radiation and vapor pressure deficit (data not shown). At the end of the growing season, EBC increased. Figure 5 shows the diurnal cycles of the energy fluxes as well as energy residual during the different OPs. Figure 6 shows graphically EBC in both years. The slope of the regression line, forced through the origin, of the available energy on the turbulent energy was 0.71 in 2012. In 2013 it was 0.64 .

\subsection{Evapotranspiration measurements}

\subsubsection{Growing season 2012}

The results of the geostatistical analysis, performed for the OPs in which soil was sampled down to $1.5 \mathrm{~m}$, showed that the $16 \Delta S$ sampling points were not or only weakly spatially correlated. Computing the footprint-averaged $\Delta S$ with Ordinary Kriging instead of using simply the arithmetic mean of the 16 sampling points resulted in differences between 0.4 and $1.7 \mathrm{~mm}$, what corresponds to a relative error below $0.5 \%$. Therefore, the arithmetic mean was used in the following.

Applying the rain gauge correction proposed by the WMO (1999) (see Eq. 5) increased total rainfall on average by $12 \%$ in both years. In 2012, the two pumping wells stayed dry during the whole growing season (OP-1), i.e., the groundwater level was always deeper than 3 meters. Total rainfall was $305 \mathrm{~mm}$ and seepage amounted to $38 \mathrm{~mm}$ (Ta-

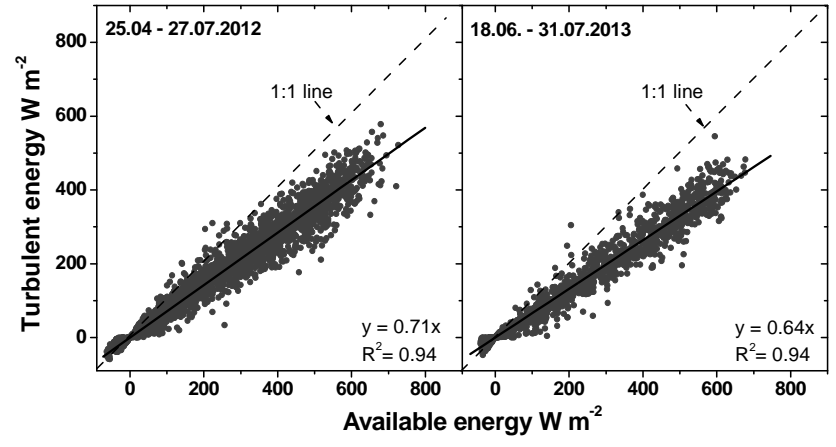

Figure 6. Scatter plots and linear regressions between turbulent and available energy in the periods from April to July 2012 and 2013. The $1: 1$ line indicates perfect energy balance closure.

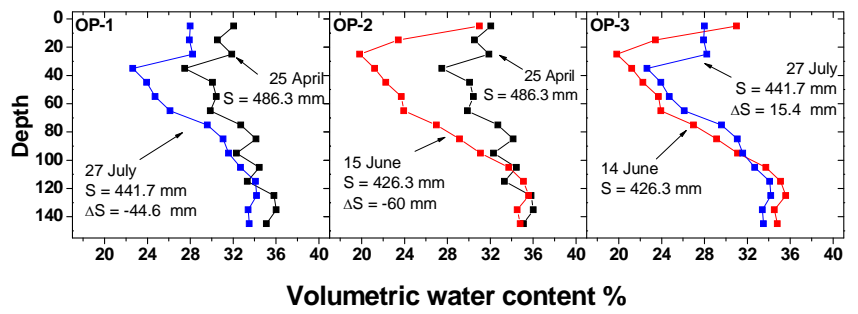

Figure 7. Vertical soil water profiles and change in water storage over three observation periods (OPs) at winter wheat stands at EC3 in 2012 .

ble 3). During the first soil sample campaign, $486.3 \mathrm{~mm}$ of water was stored in the upper $150 \mathrm{~cm}$ of soil (Fig. 7). The soil water stock decreased by 44.6 to $441.7 \mathrm{~mm}$. During OP2 , soil water storage was depleted to $426.3 \mathrm{~mm}$. During OP-3, rainfall refilled the soil water stock by $15.4 \mathrm{~mm}$. The vertical soil water profiles showed the largest differences within the upper $100 \mathrm{~cm}$ of the soil profile. Below $100 \mathrm{~cm}$ the soil water content changed only very little (Fig. 7). The components of the soil water balance and the resulting ET are compiled and compared with $\mathrm{ET}_{\mathrm{EC}}$ in Table 3. In all OPs, the best agreement of the EC technique with WB method was achieved without adjusting the LE flux data ( $H$ post-closure method). The $\mathrm{ET}_{\mathrm{EC}}$ computed with the Bowen ratio method was on average about $28 \%$ higher than $\mathrm{ET}_{\mathrm{WB}}$. The $\mathrm{ET}_{\mathrm{EC}}$ computed with the LE flux post-closure method was on average about $54 \%$ higher than $\mathrm{ET}_{\mathrm{WB}}$.

In 2012, standard error of rainfall measurements ranged from 2 to $4 \mathrm{~mm}$ depending on the observation period. Standard error of $\Delta S$ ranged from $6(1.3 \%)$ to $9(2 \%) \mathrm{mm}$. Standard error of SP ranged from 2 to $5 \mathrm{~mm}$.

\subsubsection{Growing season 2013}

Between mid-April and early June 2013, rainfall was more than twice as high as in 2012 (data not shown). The water level in the pumping wells rose to the surface for several days during this period ( 8 May and 3-5 June), and surface runoff 
Table 2. Weather conditions during the vegetation periods 2012 and 2013 . The numbers in brackets give the anomaly over an observation period with regard to the 5-year average from 2009 to 2013.

\begin{tabular}{|c|c|c|c|c|c|c|c|}
\hline \multirow{2}{*}{$\begin{array}{l}\text { Growing season, year } \\
\text { Observation period }\end{array}$} & \multicolumn{3}{|c|}{2012} & \multicolumn{4}{|c|}{2013} \\
\hline & $\begin{array}{r}25 / 04-27 / 07 \\
\text { OP-1 }\end{array}$ & $\begin{array}{r}25 / 04-15 / 06 \\
\text { OP-2 }\end{array}$ & $\begin{array}{r}14 / 06-27 / 07 \\
\text { OP-3 }\end{array}$ & $\begin{array}{r}13 / 04-26 / 04 \\
\text { OP-4 }\end{array}$ & $\begin{array}{r}05 / 07-27 / 07 \\
\text { OP-5 }\end{array}$ & $\begin{array}{r}18 / 06-31 / 07 \\
\text { OP-6 }\end{array}$ & $\begin{array}{r}15 / 04-04 / 06 \\
\text { OP-0 }\end{array}$ \\
\hline $\mathrm{BBCH}$ stage & $30-89$ & $30-65$ & $65-89$ & $20-30$ & $75-89$ & $65-89$ & $20-60$ \\
\hline Mean Net Radiation, $\mathrm{W} \mathrm{m}^{-2}$ & $148.9(+0.7)$ & $146.9(+8.5)$ & $152.6(-8.8)$ & $119.1(-5.1)$ & $192.7(+33.8)$ & $173.3(+12.5)$ & $108.5(-23.7)$ \\
\hline Mean temperature, ${ }^{\circ} \mathrm{C}$ & $16.1(+0.6)$ & $14.6(+1.0)$ & $17.9(+0.1)$ & $12.8(+2.6)$ & $19.9(+1.5)$ & $18.6(+0.6)$ & $11.1(-1.3)$ \\
\hline Average wind speed, $\mathrm{m} \mathrm{s}^{-1}$ & $1.6(-0.1)$ & $1.7(-0.1)$ & $1.5(-0.1)$ & $2.3(+0.2)$ & $1.4(-0.3)$ & $1.6(-0.0)$ & $2.3(+0.3)$ \\
\hline $\mathrm{VPD}, \mathrm{hPa}$ & $6.4(+0.5)$ & $5.9(+1.1)$ & $6.9(-0.1)$ & $6.1(+1.1)$ & $10.2(+2.3)$ & $8.2(+1.1)$ & $3.6(-1.2)$ \\
\hline Bowen Ratio (H/LE)* & $0.44(+0.07)$ & $0.19(-0.01)$ & $0.44(-0.16)$ & $0.17(-0.09)$ & $0.56(-0.53)$ & $0.5(-0.34)$ & $0.15(-0.05)$ \\
\hline Rainfall, mm & $305.0(-8.6)$ & $140.0(-50.7)$ & $166.0(+38.9)$ & $6.7(-10.3)$ & $1.6(-71.3)$ & $75.0(-59.1)$ & $282.7(+117.8)$ \\
\hline
\end{tabular}

* The Bowen ratio was computed for the period 09:00 a.m. to 03:00 p.m.

Table 3. Evapotranspiration measured with the water balance (WB) method and the eddy covariance (EC) technique at winter wheat stands in 2012 and 2013.

\begin{tabular}{|c|c|c|c|c|c|c|}
\hline \multirow{3}{*}{$\begin{array}{l}\text { Growing season, year } \\
\text { Observation period (OP) }\end{array}$} & \multicolumn{3}{|c|}{2012} & \multicolumn{3}{|c|}{2013} \\
\hline & 25/04-27/07 & $25.04-15 / 06$ & $14 / 06-27 / 07$ & $13 / 04-26 / 04$ & 05/07-27/07 & $18 / 06-31 / 07$ \\
\hline & OP-1 & OP-2 & OP-3 & OP- 4 & OP-5 & OP-6 \\
\hline Length of the period, days & 94 & 52 & 44 & 14 & 23 & 44 \\
\hline Rainfall, mm & 305 & 140 & 166 & 6.7 & 1.6 & 75 \\
\hline Water storage, $\mathrm{mm}$ & -44.6 & -60 & 15.4 & -24.5 & -67.9 & -105.2 \\
\hline Drainage/capillary rise, $\mathrm{mm}$ & $40.2 / 2.0$ & $12.7 / 2.0$ & $28.5 / 0$ & $0.3 / 0.2$ & $1.4 / 0$ & $4.8 / 0.2$ \\
\hline \multicolumn{7}{|l|}{ Average evapotranspiration, $\mathrm{mm} \mathrm{day}^{-1}$} \\
\hline WB method & $3.3 \pm 0.3$ & $3.6 \pm 0.3$ & $2.8 \pm 0.5$ & $2.3 \pm 0.5$ & $3.1 \pm 0.3$ & $3.9 \pm 0.4$ \\
\hline EC method with sensible heat flux post-closure method & $3.4 \pm 0.6$ & $3.5 \pm 0.6$ & $3.3 \pm 0.6$ & $2.3 \pm 0.4$ & $3.1 \pm 0.5$ & $3.2 \pm 0.5$ \\
\hline EC method with Bowen ratio post-closure method & $4.1 \pm 0.6$ & $4.3 \pm 0.7$ & $3.9 \pm 0.6$ & $3.3 \pm 0.5$ & $4.6 \pm 0.7$ & $4.5 \pm 0.7$ \\
\hline EC method with latent heat flux post-closure method & $4.9 \pm 0.9$ & $5.1 \pm 1.0$ & $4.8 \pm 0.8$ & $3.8 \pm 0.7$ & $5.4 \pm 0.9$ & $5.3 \pm 0.9$ \\
\hline \multicolumn{7}{|l|}{ Energy balance closure (EBC) } \\
\hline Average EBC, $\%$ & 71 & 70 & 72 & 55 & 62 & 63 \\
\hline Average residual, $\mathrm{W} \mathrm{m}^{-2}$ & 68.5 & 72.4 & 65.1 & 70.6 & 98.8 & 89.1 \\
\hline Number of data & $2542(57.0 \%)$ & $1426(57.7 \%)$ & $1170(56.1 \%)$ & $391(58.2 \%)$ & $695(63.0 \%)$ & $1269(60.7 \%)$ \\
\hline
\end{tabular}

was observed at the field. In this period, temperatures and vapor pressure deficits were low (data not shown). During this period, marked on Fig. 8 as OP-0, the soil water stock was filled up by $57.9 \mathrm{~mm}$. Due to exceptionally high rainfall and surface runoff, which was not measured, the calculation of $\mathrm{ET}_{\mathrm{WB}}$ is unreliable for this period, which hampered comparing the EC and WB methods.

In OP-6, soil water storage decreased by 105.2 to $398.7 \mathrm{~mm}$ (Fig. 8). The total rainfall for this period was about $50 \%$ less than that in 2012 (Table 2). Seepage was low, about $4.6 \mathrm{~mm}$, over this period. Table 3 compares ET WB with $\mathrm{ET}_{\mathrm{EC}}$. In OP-6, better agreement of the EC technique with WB method was achieved by adjusting the LE flux data with the $\mathrm{BR}$ and $H$ post-closure method. The $\mathrm{ET}_{\mathrm{EC}}$ post-closed with the BR method was about $15 \%$ higher than the $\mathrm{ET}_{\mathrm{WB}}$. The $\mathrm{ET}_{\mathrm{EC}}$ computed with the $H$ post-closure method was about $18 \%$ lower than the ET derived from the WB method. The $\mathrm{ET}_{\mathrm{EC}}$ adjusted with the LE post-closure method was $36 \%$ higher than the $\mathrm{ET}_{\mathrm{WB}}$.
Soil water profiles of OP-4 and OP-5 are shown in Fig. 8 . $\mathrm{ET}_{\mathrm{WB}}$ agreed best with non-adjusted raw $\mathrm{ET}_{\mathrm{EC}}(H$ postclosure method), while BR and LE post-closure methods significantly overestimated ET by about 46 and $70 \%$, respectively (Table 3).

In 2013, standard error of rainfall measurements ranged from 0.1 to $3.5 \mathrm{~mm}$ depending on the observation period. Standard error of $\Delta S$ was $8 \mathrm{~mm}(1.7 \%)$. The standard error of the water storage measured with SM1 sensors was on average $3 \mathrm{~mm}(1.0 \%)$, and the standard error of SP was up to $1 \mathrm{~mm}$.

\section{Discussion}

The EBCs of the present study agree with those of other studies performed over agricultural land, where EBCs are typically characterized by high energy residuals (20-40\%) (Charuchittipan et al., 2014; Foken, 2008a; Panin and Bernhofer, 2008; Stoy et al., 2013). The random errors of our EC 

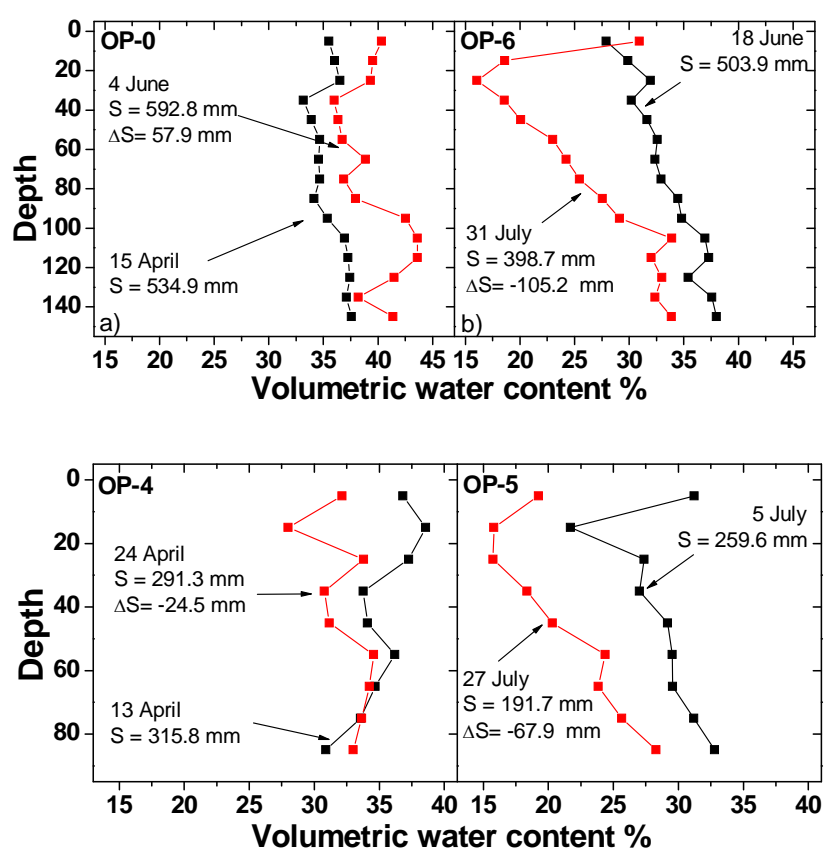

Figure 8. Vertical soil water profiles and change in water storage over four observation periods (OPs) at winter wheat stands at EC1 in 2013. The upper row shows the results of the soil sample campaigns. The soil water contents measured with capacitance soil moisture probes (SM1, Adcon Telemetry, Austria) are shown in the lower row.

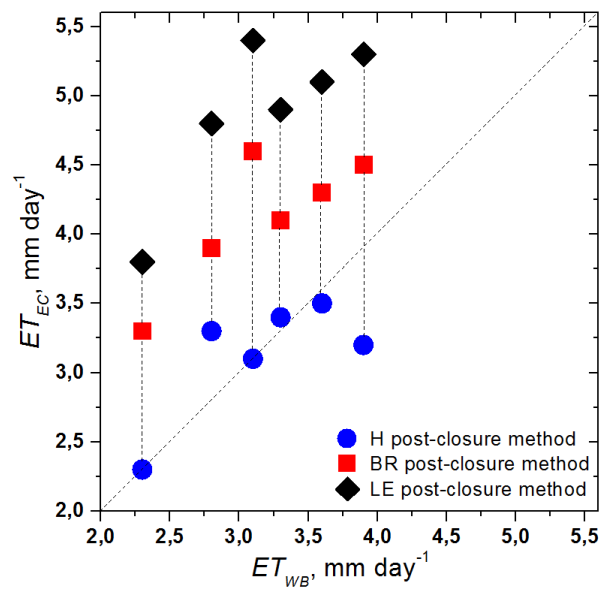

Figure 9. Scatter plots between evapotranspiration assessed from the soil water balance, $\mathrm{ET}_{\mathrm{WB}}$, and evapotranspiration measured by the eddy covariance technique, $\mathrm{ET}_{\mathrm{EC}}$, adjusted by the sensible heat flux $(H)$, the Bowen ratio (BR) and the latent heat flux (LE) postclosure method.

fluxes are also in a good agreement with random errors reported by Mauder et al. (2013) and Foken (2008a). They are typically between 5 and $20 \%$ for high-quality data.

Our experiment showed the limits of the WB method imposed by the prevailing weather conditions. It was not pos- sible to reliably estimate $\mathrm{ET}_{\mathrm{WB}}$ in periods with heavy rain due to the uncertainties in drainage calculation and surface runoff. Ideal conditions for performing the WB method are periods with low precipitation and low or absent seepage, and with soil water contents below field capacity (Schume et al., 2005; Wilson et al., 2001). These conditions were well fulfilled during OP 4 and 5. During OP4 and OP5 we found a nearly perfect match between the WB method and the nonadjusted ET data. The results that we obtained during OPs with higher seepage fluxes (OP1-3) are in line with the findings of OP4 and 5. Therefore, we are confident that the estimated seepage fluxes are in the right order of magnitude and that the total error, which is relatively low due to the small absolute flux, is in an acceptable range.

The comparison of the two methods shows that the EC method reliably measures evapotranspiration when no adjustment is applied (Fig. 9). Similar results were obtained in other experimental studies. Schume et al. (2005) crosschecked ET measured with the EC technique against the soil water balance method over a mixed European beech - Norway spruce forest. The observed EBC ranged between 73 and $92 \%$ at their study site. They demonstrated that ET was adequately measured with the EC technique. They concluded that the proportional distribution of the residual between the energy balance components would lead to an overestimation of LE. Wilson et al. (2001) compared non-adjusted ET $_{\mathrm{EC}}$ with $\mathrm{ET}$ measured by various other measurement techniques. EBC was $80 \%$. They reported a good agreement between $\mathrm{ET}_{\mathrm{EC}}$ and ET assessed by the catchment water balance method. Both methods estimated nearly equal annual ET over a 5-year period. They also observed a high correlation $\left(R^{2}=0.8\right)$ between $\mathrm{ET}_{\mathrm{EC}}$ and $\mathrm{ET}$ assessed by the soil water budget method. Nonetheless, the data were highly variable during periods with rainfall and rapid water movement within the soil profile.

Contrasting results were obtained in other similar studies, i.e., where independently measured ET was compared with $\mathrm{ET}_{\mathrm{EC}}$. For instance, Barr et al. (2012) compared measured streamflow from the watershed with streamflow, estimated from seven flux towers in this watershed, over a 10-year period. The annual EBC was about $85 \%$ across sites and years. His results showed that measured streamflow better agreed with outflow estimated based on the $\mathrm{ET}_{\mathrm{EC}}$ adjusted with the $\mathrm{BR}$ method, whereas outflow based on the raw $\mathrm{ET}_{\mathrm{EC}}$ flux was about $40 \%$ higher. In several other experimental studies, independently measured ET agreed better with $\mathrm{ET}_{\mathrm{EC}}$ adjusted by one of the post-closure methods. Wohlfahrt et al. (2010) cross-checked $\mathrm{ET}_{\mathrm{EC}}$ against ET determined using micro-lysimeters and an approach scaling up leaf-level stomatal conductance to canopy-level transpiration. The observed EBC was about $85 \%$. The best correspondence between EC and the independent methods was achieved with the LE post-closure method. Gebler et al. (2015) found that $\mathrm{ET}_{\mathrm{EC}}$ adjusted with $\mathrm{BR}$ post closure method yielded the best fit with $\mathrm{ET}$ measured by lysimeters, while raw $\mathrm{ET}_{\mathrm{EC}}$ 
was $16 \%$ smaller and $\mathrm{ET}_{\mathrm{EC}}$ adjusted with LE post-closure method was $15.7 \%$ higher. Cuenca et al. (1997) conducted intensive field campaigns (IFC) in spring and summer using a neutron probe and time domain reflectometry to evaluate the soil water content at a boreal forest. During IFC1 he reported a good agreement between unadjusted $\mathrm{ET}_{\mathrm{EC}}$ $\left(2.9 \mathrm{~mm} \mathrm{day}^{-1}\right)$ and ET estimated based on the soil water profile analysis $\left(2.6 \mathrm{~mm} \mathrm{day}^{-1}\right)$. During IFC-2, however, the difference between the two methods was extremely high: $3.6 \mathrm{~mm} \mathrm{day}^{-1}$ against $2.1 \mathrm{~mm} \mathrm{day}^{-1}$, respectively. They related this difference to the spatial differences and sampling volume of the measurement techniques. They also suggested that the $\mathrm{ET}_{\mathrm{WB}}$ versus $\mathrm{ET}_{\mathrm{EC}}$ difference could be due to the underestimation by the turbulent complex of the downward (negative) LE flux at night, which would overestimate the LE flux.

Our results synthesized with the findings from literature suggest that there is no universal approach to post-close the energy balance gap, and that the composition of the energy residual is site-specific. Therefore, it is advisable in case of long-term experiments to perform for each site at the very beginning an independent measurement of LE to identify the most suitable post-closure method. Moreover, if EC flux data are intended to be used to calibrate and parameterize, for example, a land surface model, as in our case, biased measured turbulent fluxes would directly affect the outcome of these calibration efforts and lead to systematically biased simulated turbulent fluxes. Therefore, an elaborated study on the energy residual and its major components measured by the EC system should be mandatory in such research studies.

The energy residual was higher at EC1 $(40 \%)$ in comparison with EC3 (29\%). This might be partly assigned to the heterogeneity of the EC station surrounding (Stoy et al., 2013). A hilly forested area is situated about $500 \mathrm{~m}$ south from the EC1 station (Figs. 1 and 3) which might have led to formation of stationary large eddies over the field. Their transport of energy and matter cannot be detected by the EC station leading to lower EBC at this study field. However, as already stressed in the Introduction, the large eddy theory has not been fully embraced by the scientific community (see e.g., Leuning et al., 2012). The worst closure during OP-4 could be assigned to additional spatial heterogeneity caused by differences in phenological development of crops in the landscape. OP-4 was performed early in the growing season. In Kraichgau region during this time some fields are already well covered with vegetation (e.g., winter cereals and winter rape) while others are still bare, prepared for late-covering crops, i.e., corn, potato, sugar beet (Imukova et al. 2015). Later in the growing season fields are more evenly covered with vegetation.

One of the possible components, which may be partly responsible for the energy imbalance at our study site, is the loss of fluxes in the low- and/or high-frequency range. Mauder and Foken (2006) estimated the low-frequency loss of EC flux data. They reported that the commonly used
30 min averaged interval of the covariances does not cover the entire spectrum of the turbulent fluxes. Extending the average time substantially reduced the residual, considerably increasing $H$ flux leaving LE practically unaltered. $H$ changed from $40.1 \mathrm{~W} \mathrm{~m}^{-2}$ with a 5 min averaging interval to $66.9 \mathrm{~W} \mathrm{~m}^{-2}$ with $24 \mathrm{~h}$. LE, in contrast, decreased from $73.9 \mathrm{~W} \mathrm{~m}^{-2}$ with $5 \mathrm{~min}$ averaging interval to $66.9 \mathrm{~W} \mathrm{~m}^{-2}$ with $24 \mathrm{~h}$, although with an averaging time of multiple days, LE was about $75 \mathrm{~W} \mathrm{~m}^{-2}$. Wolf and Laca (2007) performed a cospectra analysis of the $\mathrm{ET}_{\mathrm{EC}}$ measured over short-grass steppes. They found that $H$ flux was underestimated by $14 \%$ due to the lack of measurement resolution in the highfrequency range. The LE loss was only half of the $H$ loss. They concluded that this must lead to a bias in the measured Bowen ratio.

Other possible candidates of the energy imbalance at our study site are underestimated ground heat flux and neglected terms such as energy storage in the canopy and energy consumption by photosynthesis. Accounting for these fluxes would probably help to improve the EBC at our study site. Jacobs et al. (2008), for example, showed that EBC could be improved at a grassland site by $15 \%$ by elaborate estimation of ground heat flux (9\%) and considering energy consumption by photosynthesis and other minor storage terms such as enthalpy storage in the air layer between turbulent complex and the land surface (6\%). Meyers and Hollinger (2004) demonstrated that combining soil heat storage with canopy heat and photosynthetic energy flux improved the EBC by 15 and $7 \%$ for a fully developed maize and soybean site, respectively. They found that photosynthetic energy flux can reach, on a half-hourly basis, up to $30 \mathrm{~W} \mathrm{~m}^{-2}$ at midday. A maximum of the canopy heat storage was observed in the early morning hours (up to $20 \mathrm{~W} \mathrm{~m}^{-2}$ ). Oncley et al. (2007) report that the average heat storage by the canopy was about $10 \mathrm{~W} \mathrm{~m}^{-2}$ on a flood-irrigated cotton field, whereas the photosynthetic energy flux peaked at $48 \mathrm{~W} \mathrm{~m}^{-2}$ with a diurnal average of $8 \mathrm{~W} \mathrm{~m}^{-2}$. Guo et al. (2009) observed a decrease of EBC with the physiological development of maize. EBC was about $89 \%$ on bare soil and $67 \%$ during the senescence phase of the maize at the same field. Accordingly, the study concluded that heat storage and photosynthesis energy of the vegetation canopy play a non-negligible role in energy balance closure. In summary, our results imply that at our study site during most observation periods of the growing season (OP 1-5), the energy balance residual was not made up by latent heat. At our study site, the energy balance residual most probably consists of a combination of underestimated heat fluxes and neglected storage terms.

\section{Conclusions}

We cross-checked the evapotranspiration (ET) data obtained with the eddy covariance (EC) method against ET data measured with the soil water balance (WB) method. Both mea- 
surements were performed at winter wheat stands in southwest Germany in 2 years, 2012 and 2013. At the study site, both the Bowen-ratio and the LE post-closure method led to substantially higher ET than the WB method. In general, ET measured with the WB method agreed best with the raw non-adjusted ET fluxes (sensible heat flux $(H)$ post-closure method). Only at the end of the vegetation season 2013, during a period with high and frequent rainfall, $\mathrm{ET}_{\mathrm{WB}}$ was in-between the $\mathrm{ET}_{\mathrm{EC}}$ adjusted by the $H$ and Bowen ratio method, respectively. The LE post-closure method strongly overestimated LE during all OPs is not suitable for this site. Our study also illustrates the limits of the WB method. The lower the rainfall and seepage, the more reliable the method. At our study site, during most observation periods (OP 1-5), the energy balance gap was not made up by latent heat. This calls for considering other fluxes and storage terms to even out the energy balance.

Acknowledgements. The present study was supported by the German Research Foundation (DFG) in the framework of the Research Unit (RU) 1695 "Structure and function of agricultural landscapes under global climate change - Processes and projections on regional scale" and in part by Erasmus Mundus grant SGA 2010-2361. We thank Benedikt Prechter and Maxim Poltoradnev for the great help in conducting the soil sampling campaigns and installing the soil moisture network.

Edited by: P. Stoy

\section{References}

Barr, A. G., King, K. M., Gillespie, T. J., den Hartog, G., and Neumann, H. H.: A comparison of Bowen ratio and eddy correlation sensible and latent heat flux measurements above deciduous forest, Bound.-Lay. Meteorol., 71, 21-41, 1994.

Barr, A. G., van der Kamp, G., Black, T. A., McCaughey, J. H., and Nesic, Z.: Energy balance closure at the BERMS flux towers in relation to the water balance of the White Gull Creek watershed 1999-2009, Agr. Forest Meteorol., 153, 3-13, 2012.

Charuchittipan, D., Babel, W., Mauder, M., Leps, J.-P., and Foken, T.: Extension of the Averaging Time in Eddy-Covariance Measurements and Its Effect on the Energy Balance Closure, Bound.Lay. Meteorol., 152, 303-327, 2014.

Cuenca, R. H., Stangel, D. E., and Kelly, S. F.: Soil water balance in a boreal forest, J. Geophys. Res.-Atmos., 102, 29355-29365, 1997.

Currell, G. and Dowman, A.: Essential mathematics and statistics for science, The University of the West of England, UK, 2009.

Dane, J. H. and Topp, G. C.: Methods of soil analysis, Part 4 Physical methods: Soil Science Society of America Book Series No. 5, Soil Science Society of America, Madison, Wisconsin, 2002

de Vries, D. A.: Thermal properties of soils, in: Physics of Plant Environment, edited by: W. R. van Wijk, North-Holland Publishing Co., Amsterdam, 210-235, 1963.
Durner, W.: Hydraulic conductivity estimation for soils with heterogeneous pore structure, Water Resour. Res., 30, 211-223, 1994.

El Maayar, M., Chen, J. M., and Price, D. T.: On the use of field measurements of energy fluxes to evaluate land surface models, Ecol. Model., 214, 293-304, 2008.

Falge, E., Baldocchi, D., Olson, R., Anthoni, P., Aubinet, M., Bernhofer, C., Burba, G., Ceulemans, R., Clement, R., Dolman, H., Granier, A., Gross, P., Grünwald, T., Hollinger, D., Jensen, N.O., Katul, G., Keronen, P., Kowalski, A., Lai, C. T., Law, B. E., Meyers, T., Moncrieff, J., Moors, E., Munger, J. W., Pilegaard, K., Rannik, Ü, Rebmann, C., Suyker, A., Tenhunen, J., Tu, K., Verma, S., Vesala, T., Wilson, K., and Wofsy, S.: Gap filling strategies for defensible annual sums of net ecosystem exchange, Agr. Forest Meteorol., 107, 43-69, 2001.

Falge, E., Reth, S., Brüggemann, N., Butterbach-Bahl, K., Goldberg, V., Oltchev, A., Schaaf, S., Spindler, G., Stiller, B., Queck, R., Köstner, B., and Bernhofer, C.: Comparison of surface energy exchange models with eddy flux data in forest and grassland ecosystems of Germany, Ecol. Model., 188, 174-216, 2005.

Foken, T.: The energy balance closure problem: An overview, Ecol. Appl., 18, 1351-1367, 2008a.

Foken, T.: Micrometeorology, Heidelberg, Springer, 308 pp., 75 cloth, ISBN: 978354074665 2, 2008b.

Foken, T., Mauder, M., Liebethal, C., Wimmer, F., Beyrich, F., Leps, J.-P., Raasch, S., DeBruin, H. A. R., Meijninger, W. M. L., and Bange, J.: Energy balance closure for the LITFASS-2003 experiment, Theor. Appl. Climatol., 101, 149-160, 2010.

Friedrich, K., Mölders, N., and Tetzlaff, G.: On the influence of surface heterogeneity on the Bowen-Ratio: A theoretical case study, Theor. Appl. Climatol., 65, 181-196, 2000.

Gayler, S., Ingwersen, J., Priesack, E., Wöhling, T., Wulfmeyer, V., and Streck, T.: Assessing the relevance of subsurface processes for the simulation of evapotranspiration and soil moisture dynamics with CLM3.5: Comparison with field data and crop model simulations, Environ. Earth Sci., 69, 415-427, 2013.

Gebler, S., Hendricks Franssen, H.-J., Pütz, T., Post, H., Schmidt, M., and Vereecken, H.: Actual evapotranspiration and precipitation measured by lysimeters: a comparison with eddy covariance and tipping bucket, Hydrol. Earth Syst. Sci., 19, 2145-2161, doi:10.5194/hess-19-2145-2015, 2015.

Göckede, M., Markkanen, T., Hasager, C. B., and Foken, T.: Update of a footprint-based approach for the characterisation of complex measurement sites, Bound.-Lay. Meteorol., 118, 635-655, 2006.

Guo, J. X., Bian, L. G., and Dai, Y. J.: Multiple time scale evaluation of the energy balance during the maize growing season, and a new reason for energy imbalance, Sci. China Ser. D, 52, 108$117,2009$.

Heusinkveld, B. G., Jacobs, A. F. G., Holtslag, A. A. M., and Berkowicz, S. M.: Surface energy balance closure in an arid region: Role of soil heat flux, Agr. Forest Meteorol., 122, 21-37, 2004.

Imukova, K., Ingwersen, J., and Streck, T.: Determining the spatial and temporal dynamics of the green vegetation fraction of croplands using high-resolution RapidEye satellite images, Agr. Forest Meteorol., 206, 113-123, 2015.

Inagaki, A., Letzel, M. O., Raasch, S., and Kanda, M.: Impact of surface heterogeneity on energy imbalance: A study using LES, J. Meteorol. Soc. Jpn., 84, 187-198, 2006. 
Ingwersen, J., Steffens, K., Högy, P., Warrach-Sagi, K., Zhunusbayeva, D., Poltoradnev, M., Gäbler, R., Wizemann, H.-D., Fangmeier, A., Wulfmeyer, V. and Streck, T.: Comparison of Noah simulations with eddy covariance and soil water measurements at a winter wheat stand, Agr. Forest Meteorol., 151, 345-355, 2011.

IUSS Working Group WRB,: World Reference Base for Soil Resources 2006, First Update 2007, World Soil Resources Reports, FAO, Rome, 2007.

Jacobs, A. F. G., Heusinkveld, B. G., and Holtslag, A. A. M.: Towards closing the surface energy budget of a mid-latitude grassland, Bound.-Lay. Meteorol., 126, 125-136, 2008.

Kanda, M., Inagaki, A., Letzel, M. O., Raasch, S., and Watanabe, T.: Les study of the energy imbalance problem with eddy covariance fluxes, Bound.-Lay. Meteorol., 110, 381-404, 2004.

Klaassen, W. and Sogachev, A.: Flux footprint simulation downwind of a forest edge, Bound.-Lay. Meteorol., 121, 459-473, 2006.

Lamaud, E., Ogée, J., Brunet, Y., and Berbigier, P.: Validation of eddy flux measurements above the understorey of a pine forest, Agr. Forest Meteorol., 106, 187-203, 2001.

Leuning, R., van Gorsel, E., Massman, W. J., and Isaac, P. R.: Reflections on the surface energy imbalance problem, Agr. Forest Meteorol., 156, 65-74, 2012.

Mauder, M. and Foken, T.: Impact of post-field data processing on eddy covariance flux estimates and energy balance closure, Meteorol. Z., 15, 597-609, 2006.

Mauder, M. and Foken. T.: Documentation and Instruction Manual of the Eddy-Covariance Software Package TK3, Arbeitsergebnisse Nr. 46, Universität Bayreuth, Abteilung Mikrometeorologie, ISSN 1614-8916, Bayreuth, 2011.

Mauder, M., Desjardins, R. L., and MacPherson, I.: Scale analysis of airborne flux measurements over heterogeneous terrain in a boreal ecosystem, J. Geophys. Res.-Atmos., 112, D13112, doi:10.1029/2006JD008133, 2007.

Mauder, M., Cuntz, M., Drüe, C., Graf, A., Rebmann, C., Schmid, H. P., Schmidt, M., and Steinbrecher, R.: A strategy for quality and uncertainty assessment of long-term eddy-covariance measurements, Agr. Forest Meteorol., 169, 122-135, 2013.

Meyers, T. P. and Hollinger, S. E.: An assessment of storage terms in the surface energy balance of maize and soybean, Agr. Forest Meteorol., 125, 105-115, 2004.

Moore, C. J.: Frequency response corrections for eddy correlation systems, Bound.-Lay. Meteorol., 37, 17-35, 1986.

Oncley, S. P., Foken, T., Vogt, R., Kohsiek, W., DeBruin, H. A. R., Bernhofer, C., Christen, A., van Gorsel, E., Grantz, D., Feigenwinter, C., Lehner, I., Liebethal, C., Liu, H., Mauder, M., Pitacco, A., Ribeiro, L., and Weidinger, T.: The energy balance experiment EBEX-2000. Part I: Overview and energy balance, Bound.Lay. Meteorol., 123, 1-28, 2007.

Panin, G. N. and Bernhofer, C.: Parametrization of turbulent fluxes over inhomogeneous landscapes, Izv. Atmos. Ocean Phy., 44, 701-716, 2008.

Peters, A. und Durner, W.: Improved estimation of soil water retention characteristics from hydrostatic column experiments, Water Resour. Res., 42, W1140, doi:10.1029/2006WR004952, 2006
Sakai, R. K., Fitzjarrald, D. R., and Moore, K. E.: Importance of low-frequency contributions to eddy fluxes observed over rough surfaces, J. Appl. Meteorol., 40, 2178-2192, 2001.

Schotanus, P., Nieuwstadt, F. T. M., and De Bruin, H. A. R.: Temperature measurement with a sonic anemometer and its application to heat and moisture fluxes, Bound.-Lay. Meteorol., 26, 81-93, 1983.

Schume, H., Hager, H., and Jost, G.: Water and energy exchange above a mixed European Beech - Norway Spruce forest canopy: A comparison of eddy covariance against soil water depletion measurement, Theor. Appl. Climatol., 81, 87-100, 2005.

Stoy, P. C., Mauder, M., Foken, T., Marcolla, B., Boegh, E., Ibrom, A., Arain, M. A., Arneth, A., Aurela, M., Bernhofer, C., Cescatti, A., Dellwik, E., Duce, P., Gianelle, D., van Gorsel, E., Kiely, G., Knohl, A., Margolis, H., Mccaughey, H., Merbold, L., Montagnani, L., Papale, D., Reichstein, M., Saunders, M., Serrano-Ortiz, P., Sottocornola, M., Spano, D., Vaccari, F., and Varlagin, A.: A data-driven analysis of energy balance closure across FLUXNET research sites: The role of landscape scale heterogeneity, Agr. Forest Meteorol., 171-172, 137-152, 2013.

Tsvang, L. R., Fedorov, M. M., Kader, B. A., Zubkovskii, S. L., Foken, T., Richter, S. H., and Zeleny, Y.: Turbulent exchange over a surface with chessboard-type inhomogeneities, Bound.-Lay. Meteorol., 55, 141-160, 1991.

Twine, T. E., Kustas, W. P., Norman, J. M., Cook, D. R., Houser, P. R., Meyers, T. P., Prueger, J. H., Starks, P. J., and Wesely, M. L.: Correcting eddy-covariance flux underestimates over a grassland, Agr. Forest Meteorol., 103, 279-300, 2000.

UMS GmbH: User Manual HYPROP, Germany, 2012.

UMS GmbH: Operation Manual KSAT, Germany, 2013.

Webb, E. K., Pearman, G. I., and Leuning, R.: Correction of flux measurements for density effects due to heat and water vapour transfer, Q. J. Roy. Meteor. Soc., 106, 85-100, 1980.

Wilson, K., Goldstein, A., Falge, E., Aubinet, M., Baldocchi, D., Berbigier, P., Bernhofer, C., Ceulemans, R., Dolman, H., Field, C., Grelle, A., Ibrom, A., Law, B. E., Kowalski, A., Meyers, T., Moncrieff, J., Monson, R., Oechel, W., Tenhunen, J., Valentini, R., and Verma, S.: Energy balance closure at FLUXNET sites, Agr. Forest Meteorol., 113, 223-243, 2002.

Wilson, K. B., Hanson, P. J., Mulholland, P. J., Baldocchi, D. D., and Wullschleger, S. D.: A comparison of methods for determining forest evapotranspiration and its components: Sap-flow, soil water budget, eddy covariance and catchment water balance, Agr. Forest Meteorol., 106, 153-168, 2001.

Wohlfahrt, G., Irschick, C., Thalinger, B., Hörtnagl, L., Obojes, N., and Hammerle, A.: Insights from independent evapotranspiration estimates for closing the energy balance: A grassland case study, Vadose Zone J., 9, 1025-1033, 2010.

Wolf, A. and Laca, E. A.: Cospectral analysis of high frequency signal loss in eddy covariance measurements, Atmos. Chem. Phys. Discuss., 7, 13151-13173, doi:10.5194/acpd-7-131512007, 2007.

World Meteorological Organization (WMO): Instruments and Observing Methods - WMO Field intercomparison of rain intensity gauges, Report No. 99, 2009. 